\title{
AC 2010-1239: CONSTRUCTION INDUSTRY INVOLVEMENT IN THE CAPSTONE SENIOR DESIGN CLASS
}

\section{Althea Arnold, University of North Texas}

Dr. Althea Arnold is an assistant professor at the University of North Texas. She earned her Ph.D. from Texas A\&M University in the Department of Architecture, Construction Management specialty and her MS and BS in Civil Engineering. She has worked as a civil engineer, researcher, and faculty member with more than 25 years combined experience. She coordinates and teaches the capstone senior design class for Construction Engineering Technology. Her interests include Building Information Modeling (BIM), Leadership in Energy and Environmental Design (LEED), and robotics in construction. 


\section{Construction Industry Involvement in the Capstone Senior Design Class}




\begin{abstract}
The University of North Texas Construction Engineering Technology program has effectively taken advantage of construction industry involvement in the implementation of its capstone class. The objectives of this capstone experience are to integrate the knowledge learned in all previous course work, give the student experience working with industry that was not possible in conventional classroom settings, expose the students to cutting edge technology currently being used by progressive industries, give students experience working in teams and making both written and oral presentations. These objectives are in line with the ABET requirements for capstone courses: (1) "draw together diverse elements of the curriculum," and (2) "develop student competence in focusing both technical and non-technical skills in solving problems." The Senior Design capstone course is a two semester course pair required of all graduating seniors in the degree program. Students in these courses closely follow actual construction projects over the nine month course duration. Students choose from projects in commercial construction, residential subdivision construction, heavy highway or structural design. Although students follow an actual project they are responsible for developing their own schedule, cost estimate, and 3-D Revit building model. Students learn how early decisions affect the cost and schedule of the project. For their final presentation, students present the actual project; their own projections; recommendations for making the project more sustainable; and comparisons for each. These presentations are made before members of the Construction Industry Advisory Board, faculty, and other students. This paper discusses the advantages and disadvantages of using actual construction projects as a backdrop for the capstone class and of working directly with the construction industry as an educational experience. The success of this first year has lead to continued interest from the construction community to be part of this program.
\end{abstract}

\title{
Introduction
}

Capstone design courses are recognized as an important part of the Engineering curriculum. ${ }^{1}$ The University of North Texas Construction Engineering Technology program is a new program that has recently graduated its first undergraduate class. Due to the small class size and newness of the program, it was necessary to determine an effective and economical way of meeting the students various needs in a capstone course. Larger universities divide their capstone classes into sections reflecting the student specialties, i.e. residential, commercial and heavy highway construction. With the first graduating class at 16 students and the second to be 11 students, dividing the class into different sections is impractical.

It is also desirable to provide educational objectives that meet industries' needs while making students competitive in the employment market. A study of capstone courses ${ }^{2}$ showed that there was a gap between what faculty emphasizes and the corresponding industry expectations. Directly involving industry in the capstone class closes this gap.

The construction program is in the Department of Engineering Technology; accordingly the senior design class was patterned after the established curriculum which consists of two consecutive two-hour courses taken in the senior year. This is ideal for construction in that two semesters (nine months) time is sufficient to follow a construction project. This led to the need to 
contact construction companies to gain their assistance in acquiring projects.. The Industrial Advisory Board (IAB) was the obvious choice to begin this search and was instrumental in recommending projects. This also led to increasing the membership of the program's IAB. A more detailed explanation of the course content can be found in the paper "Senior Design Capstone -- Lessons Learned from Our First Year." 3 A brief description of the course content is discussed below in "Course Layout."

This paper will discuss the objectives of the course; how it meets ABET criterion, and the advantages and disadvantages of industry involvement in the Senior Design Capstone course.

\section{Background Study}

The paper " Capstone Design Courses and Assessment: a National Study"1 states that "a significant number of institutions engage industrial clients to sponsor capstone projects" but does not elaborate on how sponsors are engaged, the type of projects provided or the benefit to the students in this process or the advantages or disadvantages of the process. Howe, et al. performed a study on the content in capstone courses ${ }^{2}$. This study focused "on the design, project and professional attributes associated with capstone engineering courses". The study performed a survey to determine course content and its importance from student, faculty, and industry perspectives. This report found that industry places different emphasis on learning topics than do faculty. Professional topics rated high in importance to industry. This was seen in the topics that guest speakers from industry presented. Almost all of the speakers invited to the capstone course spent a large portion of their talk on professional topics such as ethics, membership in professional societies, and professional presentation. The study also noted industry's comments that students lacked the knowledge of how technical skills in college were applied in the work environment. The close relationship between industry and students in this capstone course has helped bridge the gap between what is learned in the college curriculum and what industry expects of the entry level graduate.

\section{Objectives}

ABET Criterion 5 Curriculum sets requirements for capstone courses: (1) "draw together diverse elements of the curriculum," and (2) "develop student competence in focusing both technical and non-technical skills in solving problems." "4 Capstone courses are also evaluated through ABET Criterion 3 Program Outcomes (a-k) and Criterion 4 Continuous Improvement.

The objectives set by the faculty are to integrate the knowledge learned in all previous course work, give the student experience working with industry that was not possible in conventional classroom settings, expose the students to cutting edge technology currently being used by progressive industries, give students experience working in teams and making both written and oral presentations. This follows the ABET Criterion 3 and 4 requirements.

The first Criterion 5 ABET requirement is to integrate the knowledge learned in all previous course work. By following an actual ongoing project, the students learn how the classes connect to each other and their relevance to the construction process. By working with professionals in 
the field, students experience how the technical information learned in their college studies is utilized in a professional work environment.

Working directly with industry also exposes the students to cutting edge technology currently being used that is not possible to duplicate in the classroom. During the course of the semester, industry representatives were invited to make presentations to the class on various topics. Students also take field trips to construction sites. Students were required to write a one page paper on how the presentation or field trip applied to their particular project and their career goals. These papers were very enlightening in that students expressed their opinions of the relevance of the topics. A majority of the students thought that the technical presentations were not as valuable as the professional topics. This corresponds with the findings in the pilot study by Howe et all. ${ }^{2}$

Students develop their problem solving skills through the experience gained by working with industry beyond what is possible in conventional classroom setting, thus meeting the second Criterion 5 ABET requirement. Students visit the job site; talking with managers, designers, and workers. They take photos and must make presentations to their peers in the classroom explaining what they have learned and problems they have encountered. Students are given milestones they must meet throughout the semester. These milestones include developing their own schedule, cost estimate, and 3-D Revit building model. Students learn how early decisions affect the cost and schedule of the project. This gives them experience not only in meeting a time line but managing their work load and information requests from industry to meet these milestones.

Non-technical problem solving skills are developed thorough teamwork and in making both written and oral presentations. For their final reports and presentations, students present the actual project; their own projections; recommendations for making the project more sustainable; and comparisons for each. This collaborative team work gives students real world experience in solving management oriented problems.

At the conclusion of the course students made team presentations to Industry representatives, faculty, and other students. Each participant is given a booklet with the teams' brochure and a grading matrix utilizing ABET's Criterion $3 \mathrm{a}-\mathrm{k}$. An example grading matrix is shown in Figure 1. The booklets are collected at the conclusion of the presentations and the evaluations are used to determine the teams grades and are used for ABET accreditation expectations. This is an important aspect of evaluating course objectives and is compatible with methods used by other Universities. ${ }^{1}$

\section{Course Layout}

The capstone course pair is offered to students during the fall and spring semesters of their final year in the program. The first few weeks of the semester are used to help students form teams and choose projects. For their first assignment, students are instructed to write a short essay on the three major types of construction (residential, commercial, and heavy highway) and which type they would prefer to work in after graduation giving justifications. Also, during the first few weeks of the semester, industry representatives make presentations to the class on possible 
projects. Based on their essay, available projects, and student input, students are then divided into teams and are given the opportunity to choose a project from projects offered by industry, or they have found on their own.

For each project, the student team must prepare the following over the two semester time frame:

a. Existing property information, general project description, project goals, (includes site visit information, photos, and research of property information)

b. Prepare a Pro Forma analysis and discussion of project costs and benefits

c. Prepare a GAP Analysis or justification of the project along with demographic research

d. Research Environmental requirements

e. Prepare a preliminary estimate and then revise the estimate in the second semester based on project progress

f. Prepare a site logistics plan and site work layout plan (in phases as necessary)

g. Prepare a preliminary schedule using Primavera, and revise the schedule according to work progress in the second semester

h. Construct a 3-D Revit drawing of the project (or other project appropriate 3-D virtual model)

i. Prepare a "green" analysis of the project.

Milestones are given for each task which helps students schedule their time and stay on track with their project. A midterm and final report and presentation are required of each team for each semester. The final presentations for the second semester are made before the IAB and members of the industry. All students and faculty in the program are invited to the presentations. This has the added bonus of encouraging underclassmen in their studies. They have set a goal of doing better than their predecessors. 


\begin{tabular}{|c|c|c|c|c|c|c|}
\hline \multicolumn{7}{|c|}{ CNET SENIOR DESIGN RATING SHEET } \\
\hline \multicolumn{7}{|c|}{$\begin{array}{l}\text { PROJECT: Commercial Construction } \\
\text { STUDENTS: BL, WM, MK } \\
\text { Instructions: Circle the number that best represents your assessment of these students' mastery of the following Program } \\
\text { Outcomes. }\end{array}$} \\
\hline & $\begin{array}{l}\text { The content and presentation of the Senior Design project to which this student has } \\
\text { contributed clearly demonstrates: }\end{array}$ & 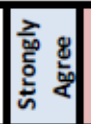 & $\frac{1}{2}$ & $\begin{array}{l}\frac{c}{\mathrm{~m}} \\
\mathrm{E} \\
\stackrel{\mathrm{J}}{5}\end{array}$ & 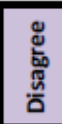 & 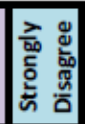 \\
\hline 1 & $\begin{array}{l}\text { an appropriate mastery of the knowledge, techniques, skills and modern tools of the } \\
\text { discipline. (a) }\end{array}$ & 5 & 4 & 3 & 2 & 1 \\
\hline 2 & $\begin{array}{l}\text { an ability to apply current knowledge and adapt to current applications of mathematics, } \\
\text { science, engineering and technology. (b) }\end{array}$ & 5 & 4 & 3 & 2 & 1 \\
\hline 3 & $\begin{array}{l}\text { an ability to conduct, analyze and interpret experiments and apply experimental results to } \\
\text { improve processes. (c) }\end{array}$ & 5 & 4 & 3 & 2 & 1 \\
\hline 4 & $\begin{array}{l}\text { An ability to apply creativity in the design of systems, components or processes appropriate } \\
\text { to program objectives. (d) }\end{array}$ & 5 & 4 & 3 & 2 & 1 \\
\hline 5 & an ability to function effectively on teams. (e) & 5 & 4 & 3 & 2 & 1 \\
\hline 6 & an ability to identify, analyze and solve technical problems. (f) & 5 & 4 & 3 & 2 & 1 \\
\hline 7 & an ability to communicate effectively. (g) & 5 & 4 & 3 & 2 & 1 \\
\hline 8 & a recognition of the need for, and an ability to engage in lifelong learning. (h) & 5 & 4 & 3 & 2 & 1 \\
\hline 9 & an ability to understand professional, ethical and social responsibilities. (i) & 5 & 4 & 3 & 2 & 1 \\
\hline 10 & $\begin{array}{l}\text { a respect for diversity and a knowledge of contemporary professional, societal and global } \\
\text { issues. (j) }\end{array}$ & 5 & 4 & 3 & 2 & 1 \\
\hline 11 & a commitment to quality, timeliness, and continuous improvement. $(\mathrm{k})$ & 5 & 4 & 3 & 2 & 1 \\
\hline 12 & producing and utilizing design, construction, and operations documents. (I) & 5 & 4 & 3 & 2 & 1 \\
\hline 13 & $\begin{array}{l}\text { performing economic analyses and cost estimates related to design, construction, and } \\
\text { maintenance of systems in the construction technical specialties. }(\mathrm{m})\end{array}$ & 5 & 4 & 3 & 2 & 1 \\
\hline 14 & selecting appropriate construction materials and practices. (n) & 5 & 4 & 3 & 2 & 1 \\
\hline 15 & applying principles of construction law and ethics. (o) & 5 & 4 & 3 & 2 & 1 \\
\hline 16 & $\begin{array}{l}\text { applying basic technical concepts to the solution of construction problems involving } \\
\text { hydraulics and hydrology, geotechnics, structures, construction scheduling and management, } \\
\text { and construction safety. (p) }\end{array}$ & 5 & 4 & 3 & 2 & 1 \\
\hline 17 & $\begin{array}{l}\text { performing standard analysis and design in at least one recognized technical specialty within } \\
\text { construction engineering technology that is appropriate to the goals of the program. (q) }\end{array}$ & 5 & 4 & 3 & 2 & 1 \\
\hline
\end{tabular}

Figure 1. Final Presentation Evaluation Sheet

\section{Industrial Advisory Board Involvement}

The IAB (Industrial Advisory Board) is comprised of construction industry professionals \& educators. They are an important asset to the development of the construction engineering program. They advise the program on curriculum development, recruitment, and advertising, and are involved in the ABET accreditation process as part of their regular duties as a board. They are a great source for industry impute because they have already expressed an interest in the education of future employees and are actively involved in the educational system. Their 
knowledge of industry requirements for entry level construction professionals helps keep the classes in sync with industry needs and their knowledge of construction industry technological developments helps keep the department on the cutting edge of the technology.

They have been invited to participate in the capstone senior design course by providing or suggesting projects, making presentations to the class, and critiquing the final project presentation. They also recommend other industry representatives to be part of the process. The Spring IAB meeting is scheduled on the same day as the senior final presentations. This has improved the attendance by the IAB members for both meetings and provided a very productive day. Attending the senior design presentations gives the IAB a sense of accomplishment and encouragement that their work on the board has been fruitful. It also encourages them to provide projects for the next year's capstone group, providing continuity from year to year.

\section{Other Professional Involvement}

While the IAB was invaluable in providing materials and recommendations, other industry professionals have also participated. Industry professionals were contacted through the AGC and NAHB local chapters. Faculty and students have spoken to the organizations at monthly meetings inviting them to participate in the construction program. The three main ways that industry supports the senior design class is by providing projects, providing site visits and field trips, and by being guest lecturers in the class room.

Projects provided have included residential subdivision designs, a strip mall, a unique auto body shop, university classroom and research facilities, and a dam project. Guest speakers have spoken on estimating, project management, LEED, codes, Utility and MEP design, and ethics. They have all brought real life experiences into the classroom and given the students the opportunity to ask questions and participate in interesting discussions. They have also provided students contacts for internships, summer jobs, and employment after graduation.

\section{Advantages}

The advantages to industry involvement in the capstone courses are mostly in the student learning and professional experience category. Directly involving industry in the capstone class closes the gap between what industry needs in entry level professionals and the corresponding perception by faulty. The industry experience brought into the classroom enhances the students learning experience and broadens the topics covered. Industry provides unmodified actual construction documents of ongoing projects for student use. Students gain an understanding of the importance of accuracy of these documents and how simple mistakes in preparing the documents can lead to problems during construction. This experience reiterates the importance of ongoing learning.

By involving a different project for each team, students can choose a specialty aligned with their career interests. Projects so far have included residential housing, commercial design build and design-bid-build, heavy civil, structural design, and LEED certified buildings. Students coordinate their own visits to the construction sites, take photos to be included in their presentations and reports, and talk with management and laborers. They have direct access to the kind of work for which their college career is preparing them. 
Lastly but just as importantly, students exposure to the industry puts them in direct contact with potential employers and employers can evaluate students on more than just a formal interview. Students have a better understanding of what will be expected of them when they enter the professional work force.

\section{Disadvantages}

The disadvantages lean more toward classroom control. Faculty has less control over the projects and students experience varies with the cooperation of the company representative. Some companies provide teams with an excessive amount of information, leaving little for the teams to do, while others provide a dearth of information.

In one instance the company representative of a very large construction firm did not provide the students with plans and specs as requested. The professor had to intervene to get a company representative that had the time and willingness to work with the students. In another instance the project was canceled after the bid was awarded (mid semester) due to owner's bankruptcy. The students were very innovative in that they found a similar project under construction by the same contractor and were able to successfully integrate the information from the two projects. While both of these experiences were problems, they were turned into learning experiences that were shared with the entire class.

Another disadvantage is the variable size of the projects. Each team must provide an estimate, schedule, and Revit model of their project. This could translate into much more work for some teams. The professor must work with the students to downsize larger projects so that the work expectations are equal for all teams.

Finally grading of the projects is made difficult by the differences in the projects. Projects cannot be graded on a comparable basis, but must be graded on their own merit. For example, a Revit drawing of a two bedroom home should include all finishes and furniture in all rooms, while a Revit drawing of a 100,000sf commercial project would have areas that are unfinished, with only a lobby or example office finished out. It is necessary to insure that students have covered all the bases of a construction project without becoming overwhelmed in any one area. And course completion requirements must take into account the size of the project and the hours students put into their projects. Industry expectations vary between companies and industry evaluations must be reviewed for fairness.

All of these disadvantages require more work from the professor than would not have been required if all teams worked on the same project. The professor must become familiar with each individual project in order to mentor the students and set individual expectations.

\section{Conclusions}

The success of this first year has lead to continued interest from the construction community to be part of this program. Industry involvement has been the best advertising medium for the new program. Industry input has enhanced the experience and depth of the class by bringing in real 
world problems and exposing students to actual ongoing construction sites. While multiple and varying sized projects require more work from the lead professor, as discussed in the disadvantages; the depth of the class is enhanced beyond what could be expected in a simple classroom setting and has been rewarding for all involved.

\section{References}

1. McKenzie, L.L., Trevisan, M.S., Davis, D.C. \& Beyerlein, S.W. (2004) Capstone design courses and assessment: A national study. ASEE Annual Conference Proceedings, 1545-1562.

2. Howe, S., Lasser, R., Su, K., and Pedicini, S. “AC 2009-1228: Content in Capstone Design Courses: Pilot Survey Results from Faculty, Students, and Industry”, American Society for Engineering Education, 2009

3. Arnold, A. "Senior Design Capstone -- Lessons Learned From Our First Year", Associated Schools of Construction Region5 Proceedings. Dallas, Texas October 2009. Worldwide web address:

http://regionv.tamu.edu/conference/proceedings.asp

4. Accreditation Board for Engineering \& Technology (ABET). (2008). Criteria for Accrediting Engineering Technology Programs. Technology Accreditation Commission. Baltimore, MD. Worldwide web address: http://www.abet.org 